\title{
Literature Reading and Writing Proficiency in Class II Elementary School Students Through Online Learning
}

\author{
Sherly Novita ${ }^{1 *}$, Zainal Rafli ${ }^{2}$, Moh. Syarif Sumantri ${ }^{1}$ \\ ${ }^{1}$ Department of Primary Education, Universitas Negeri Jakarta, Indonesia \\ ${ }^{2}$ Deparment of Language, Universitas Negeri Jakarta, Indonesia
}

\begin{abstract}
This study aims to describe the development of reading and writing literacy skills for second-grade students of SD Islam Al-Azhar 13 Rawamangun, East Jakarta. This research is a case study research that utilizes observation, interviews, document studies, and tests as data collection techniques. The development of reading and writing literacy for elementary school students in grade II begins with the emergency curriculum review process, syllabus and lesson plans design, learning implementation, and ends with an evaluation. The results of reading learning activities which consist of three activities of reading aloud reading texts, reading comprehension, and reading poetry texts indicate a very good level of students' reading skills. Writing lessons focused on writing simple poems according to pictures and writing simple texts according to pictures using punctuation marks and capital letters also showed excellent student skills. Thus, it is concluded that the online learning conducted by Al-Azhar Islamic Elementary School 13 Rawamangun to improve students' reading and writing literacy skills has been effective with various supporting factors.
\end{abstract}

Keywords: reading literacy, writing literacy, online learning.

\section{Introduction}

The School Literacy Movement (GLS) is one of the spearheads in the national Literacy Movement which is encouraged by the Ministry of Education and Culture to activate the National Literacy Movement (GLN) since 2016 as part of the implementation of the Minister of Education and Culture Regulation Number 23 of 2015 concerning the Growth of Character. GLS is a movement to cultivate student character which aims to make students have a culture of reading and writing to create lifelong learning. The form of this movement is for example a reading corner, an active library, and assignments by teachers so that students read and write a lot related to themes that are relevant to the lesson and contain moral values, local, national, and global wisdom (Sudrajat et al., 2021). The School Literacy Movement demands a comprehensive effort that involves all school members, including teachers, students, parents/guardians, and the community, as part of the educational ecosystem so that it requires collaborative support from various elements (Rachamatika et al., 2021).

On the other hand, the Covid-19 pandemic outbreak also presents new challenges for teachers and students in undergoing the online learning process (online) through various internet-based applications. At the $\mathrm{Al}$ Azhar Islamic Elementary School 13 Rawamangun where the author serves, the learning program is carried out using an online system. One of the challenges faced by teachers in online learning is that the learning interaction process is not optimal, especially for low-grade students (Asrifah et al., 2020). Teachers, in this case, must be able to design learning that remains interactive and interesting with a variety of creative activities. For 2nd-grade elementary school students, online learning as it is today is also a challenge to be able to stay active during the learning process (Marudut et al., 2020).

The utilization of information technology as an important part of the success of online learning is now increasingly facilitated by the existence of various social media such as platforms and learning management systems (LMS), both developed by world companies such as Whatsaap, Google Classroom, Microsoft 
Teams, Edmodo, and Schoology, as well as an application developed by Indonesian private schools and companies. Studies on the use of the system are quite effective in supporting learning, such as the research on the positive impact of online learning by Pujilestari (2020). In a study of the effectiveness of online learning on student learning, Prawiyodi et al. at SDIT Cendekia Purwakarta produced findings that online learning carried out at SDIT Cendekia Purwakarta with several methods was quite effective to be carried out by considering the assistance of parents (Prawiyogi et al., 2020). Research related to the implementation of online learning has also been carried out by Sari et al. (2020) about online learning during the Covid-19 emergency, and Pujilestari (2020) about the Positive Impact of Online Learning in the Indonesian Education System after the Covid-19 Pandemic.

In simple terms, literacy can be interpreted as an ability to read and write or in other terms is literacy or literacy. Currently, the meaning of literacy is expanding so that literacy does not only have a single meaning but includes several meanings so that the term multi-literacy appears (Aisyah et al., 2020). There are various kinds of literacy or literacy, for example, computer literacy, media literacy, technological literacy, economic literacy, information literacy, and moral literacy (Kardi, 2013). Reading and writing as a starting point and as basic literacy in the literacy process occupies a strategic role in supporting other literacy skills, namely numerical literacy, scientific literacy, digital literacy, financial literacy, and cultural literacy and citizenship (Atmazaki et al., 2017). Based on the above understanding, the researcher sees the importance of researching and mapping the reading and writing literacy skills of second-grade elementary school students in the online learning system along with the supporting and inhibiting factors.

\section{Literature Review}

Literacy as a concept has proven to be complex and dynamic, constantly being interpreted and defined in a variety of ways. People's ideas about what it means to be literate or illiterate are influenced by academic research, institutional agendas, national contexts, cultural values, and personal experiences (LISTYOWATI, 2018).

Reading as a starting point in the literacy process occupies a strategic role in supporting the next literacy skills, one of which is cultural literacy. Cultural literacy is intended to raise awareness of the diversity of cultures and traditions that develop in society, thereby encouraging individuals to respect and respect others who are different (Izzaty \& Nurfitriani, 2021). The ability to understand the diversity of nations and cultures as well as responsibilities as citizens are the basis of skills that every learner in this century should possess. Through reading activities in the classroom library, students can develop themselves in cultural literacy that supports the creation of dignified Indonesian citizens (Aisyah et al., 2020).

In The CONFINTEA VI by UNESCO, 2010, the conference in Belèm reaffirmed the importance of learning and literacy for the 21 st century it was mentioned that Literacy is an indispensable foundation that enables young people and adults to engage in learning opportunities at all stages of the learning continuum. The right to literacy is an inherent part of the right to education. It is a prerequisite for the development of personal, social, economic, and political empowerment. Literacy is an important means of building people's abilities to face the challenges and complexities of life, culture, economy, and developing societies (Wagner, 2013).

Early literacy skills include knowledge and abilities related to the alphabet, phonological awareness, symbolic representation, and communication. However, existing emergent literacy models focus on discrete skills and lose sight of the surrounding environment. Early literacy skills, including their relationship to one another, and the substantial impact of setting and context, are critical in ensuring that children acquire all the early skills and awareness they need to become successful readers and writers (Rohde, 2015).

Various activities that support literacy development in schools, including cultural literacy, can be carried out by utilizing various means of literacy teaching texts, such as alphabet letters, notebooks; letters of the alphabet, a sheet of paper; alphabet letters, school exams; alphabet letters, worksheets; basal reader, book; comprehension answers, notebooks; reading comprehension, cards; copy text, whiteboard; copy text, notebooks; copying texts, workbooks, serves the purpose of teaching one to read and/or write and is usually found in the domain of students' social activities in schools (Perry, 2015).

Based on a study by Prayoga et al. related to the implementation of literacy programs assisted by children's storybooks to improve students' narrative story writing skills (Prayoga et al., 2017). Reading and writing are two language skills that are interrelated and intertwined because they have many similarities (Oshchepkova \& Alkhaldi, 2018). Writing cannot be separated from other aspects of language skills. It influences and is 
influenced. The input obtained from reading and listening affects a person's writing ability. Although writing has the character that distinguishes it from other language skills (Setiadi, 2017).

The next phase, related to reading literacy according to the level of the next upper-grade elementary school student, then entering the reading comprehension phase. Reading comprehension is understood as the construction of the meaning of written or oral communication through a holistic reciprocal exchange of ideas between the interpreter and the message in a particular communicative context (McLaughlin, 2012). Writing skill is the ability to express thoughts and feelings, starting from simple things such as writing words to complex things, namely composing (Bakry \& Alsamadani, 2015).

Online learning is an important part of blended learning. Mixed learning is a learning method that combines face-to-face learning (offline) with online learning where the teacher combines the advantages of both to achieve learning objectives. Online learning is divided into several levels from the lowest, middle, and high (Nurwardani et al., n.d.). The learning mix taxonomy is divided into four parts, namely, rotation model, flex model, self-blend model, and enriched virtual model (Staker \& Horn, 2012).

\section{Method}

This research was carried out in class II SDIA 13 Rawamangun in the 2020/2021 school year. The method used is a case study with a qualitative descriptive approach that utilizes observation, interviews, and document studies to collect qualitative data related to online learning policies, the design of online reading and writing lessons and the implementation of reading and writing learning through online learning. In addition, it is also used as an instrument for collecting quantitative data related to students' reading and writing literacy skills. Second-grade elementary school students' reading skills were measured through reading aloud, poetry reading, and reading comprehension tests. Students' writing skills were measured through a test of writing text-based on pictures and writing poetry.

\section{Result and Discussion \\ Result}

Reading and writing skills are an important part of learning in elementary schools as always promoted by the Government and educational institutions in general. These two skills are part of the four language skills which in the development of these skills are included in Indonesian language lessons. The determination of basic competencies in online learning at SD Islam Al-Azhar 13 Rawamangun can be presented as follows.

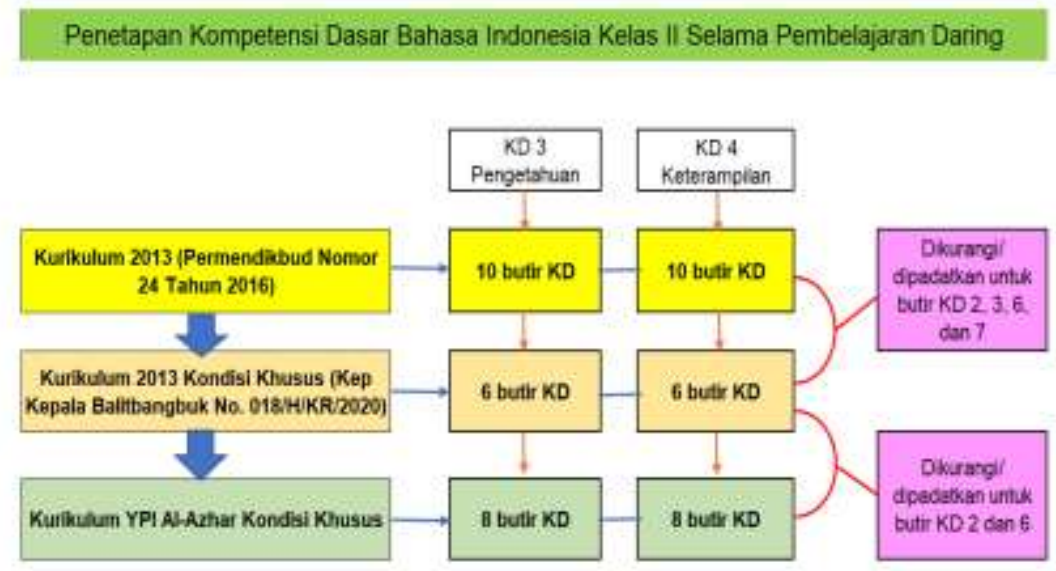

Figure 1. Basic Competencies 3 and 4 Indonesian Language in Three Online Learning Curriculum

The design of learning to read and write in class II SD Islam Al-Azhar 13 Rawamangun is prepared by following the flow starting from curriculum review, syllabus preparation, and learning implementation plans as follows. 


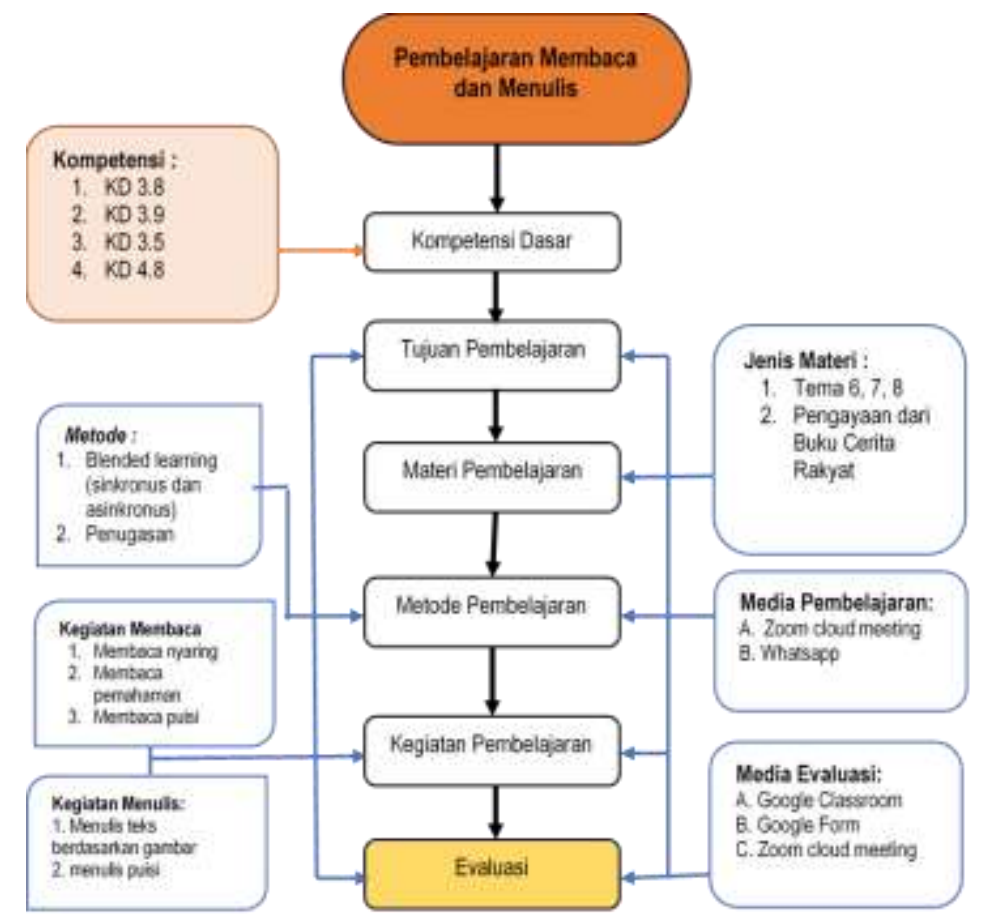

Figure 2. Schematic Flow of Reading and Writing Learning Design Online

Table 1. Recapitulation of Reading Aloud Assessment

\begin{tabular}{|c|l|c|c|}
\hline No. & Value Criteria & Frequency & Percentage (\%) \\
\hline 1 & Very Good & 7 & 20.59 \\
\hline 2 & Good & 25 & 73.53 \\
\hline 3 & Enough & 2 & 5.88 \\
\hline 4 & Need Guidance & 0 & 0 \\
\hline & Total & $\mathbf{3 4}$ & $\mathbf{1 0 0}$ \\
\hline
\end{tabular}

Table 2. Recapitulation of Reading Comprehension Assessment

\begin{tabular}{|c|l|c|c|c|c|}
\hline \multirow{2}{*}{ No. } & \multirow{2}{*}{ Value Criteria } & \multicolumn{2}{c|}{ Value 1 } & \multicolumn{2}{c|}{ Value2 } \\
\cline { 3 - 6 } & & Frequency & $\mathbf{( \% )}$ & Frequency & $(\boldsymbol{\%})$ \\
\hline 1 & Very Good & 9 & 26.47 & 10 & 29.41 \\
\hline 2 & Good & 8 & 23.53 & 12 & 35.29 \\
\hline 3 & Enough & 9 & 26.47 & 12 & 35.29 \\
\hline 4 & Need Guidance & 8 & 23.53 & 0 & 0.00 \\
\hline & Total & $\mathbf{3 4}$ & $\mathbf{1 0 0}$ & $\mathbf{3 4}$ & $\mathbf{1 0 0}$ \\
\hline
\end{tabular}

Table 3. Poetry Reading Assessment Recapitulation

\begin{tabular}{|c|l|c|c|c|c|}
\hline \multirow{2}{*}{ No. } & \multirow{2}{*}{ Value Criteria } & \multicolumn{2}{|c|}{ Value 1 } & \multicolumn{2}{c|}{ Value2 } \\
\cline { 3 - 6 } & & Frequency & $\mathbf{( \% )}$ & Frequency & $(\boldsymbol{\%})$ \\
\hline 1 & Very Good & 6 & 17.65 & 15 & 44.12 \\
\hline 2 & Good & 18 & 52.94 & 17 & 50.00 \\
\hline 3 & Enough & 10 & 29.41 & 2 & 5.88 \\
\hline 4 & Need Guidance & 0 & 0 & 0 & 0 \\
\hline & Jumlah & $\mathbf{3 4}$ & $\mathbf{1 0 0}$ & $\mathbf{3 4}$ & $\mathbf{1 0 0}$ \\
\hline
\end{tabular}




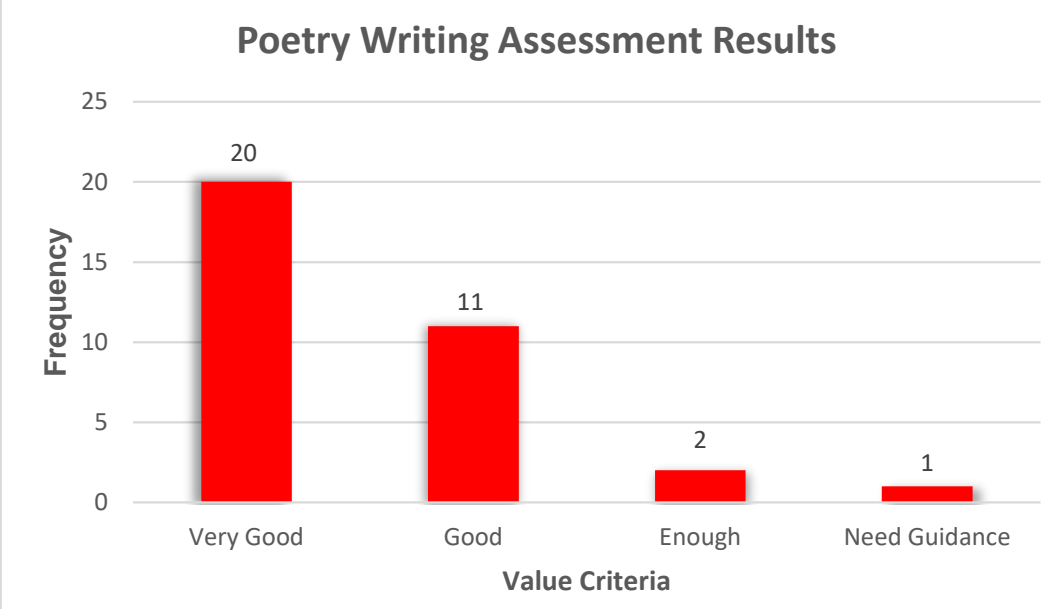

Figure 3. The results of the assessment of writing poetry for elementary school students for class II

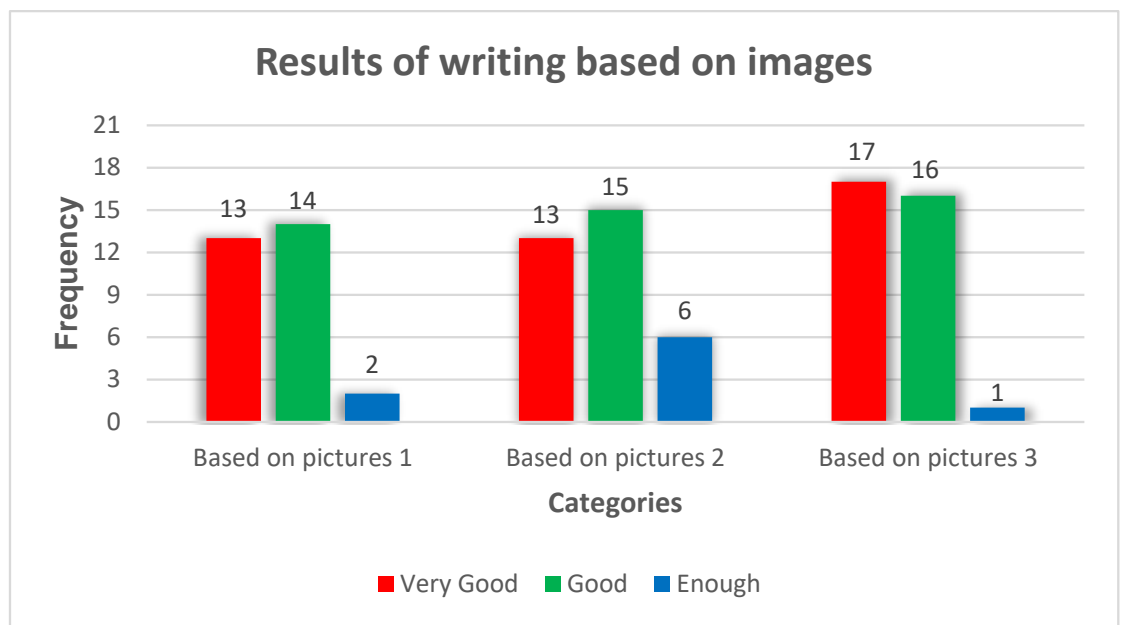

Figure 4. The assessment results of Writing Texts Based on Pictures

\section{Discussion}

Based on the research findings above, learning activities in developing reading and writing literacy are carried out according to the learning implementation plan. For reading skills, the teacher focuses activities on reading aloud, reading comprehension, and reading poetry. While the teacher's writing literacy focuses on the skills of writing text-based pictures and writing poetry. Reading and writing as early symptoms of literacy and being the focus of this research are viewed more focused and narrowed by seeing them as part of learning Indonesian. This is intended to make it easier to measure the level of literacy in these two language skills of reading and writing. Although conceptually, literacy includes all broader and general reading abilities (Muhammadi et al., 2018) and is not limited to one particular subject.

Based on the research findings, it can be seen that the online learning carried out by the Al-Azhar 13 Rawamangun Islamic Elementary School teacher is going well, with the learning process through zoom meetings every day and starting at 07.30 WIB. This daily activity begins with good habits to shape the character of the students. Repetitive activities are the best way to shape the character of grade II children who are still in an important period of personality development (Spitzer et al., 2015). As well as develop reading and writing literacy skills, the teacher tries to familiarize students with various reading and writing activities. The key to literacy is strengthening students' reading interest which is built on daily habits (Susilawati \& Marlianingsih, 2018). This habituation takes place in two activities, during learning with Zoom and with assignments outside of Zoom learning. Monitoring of this activity is carried out in conjunction with relevant learning activities such as Civic Education learning.

Based on the results of the evaluation of reading and writing skills as described in the previous section, the data shows that the reading skills of grade II elementary school students are determined in terms of reading aloud, reading comprehension, and reading poetry. While writing skills are measured on the skills of writing text-based on pictures and writing poetry. 
In general, the aloud reading skills of the second-grade students of SDI Al-Azhar Rawamangun are in a good category as many as 25 students $(73.53 \%), 7$ students $(20.59 \%)$ are in the very good category, and only 2 students $(5.88 \%)$ ) at a sufficient level. For reading comprehension results, the data shows that the test was carried out twice, where in the first test there were still 8 students who were at a low level, namely "Need Guidance". Then in the second test, better results were obtained, namely, all students who were at the "Need Guidance" level could rise to the "Enough" level, there was also an increase at other levels so that 10 students $(29.41 \%)$ were obtained in the Very Good category, 12 students (35.29\%) in the Good category, and 12 students $(35.29 \%)$ in the moderate category.

In the skill of reading aloud poetry texts which were carried out 2 times, there was a significant increase between the first and second scores, so the results of the second test showed 15 students $(44.12 \%)$ were in the Very Good category, 17 students (50\%) in the Good category, and 2 students $(5.88 \%)$ in the Enough category.

In poetry writing skills, more than half of the students achieved the very good category, namely 20 students (58.82\%), 11 students (32.35\%) in the Good category, 2 students (5.88) at the Enough level, and 1 student ( 2.94) who still need further guidance. In the writing skill based on pictures, there is an increase in grades although not quite significant, with the final result 17 students (50\%) in the Very Good category, 16 students $(47.06 \%)$ in the Good category, and 1 student $(2.94 \%)$ is in the Enough category.

Looking at the above values as a whole, it can be said that the reading and writing skills of the students of SD Islam Al-Azhar 13 Rawamangun have reached the competency standards and indicators that have been set. An increase from time to time shows that the learning process that has been implemented is running effectively. The online learning, which took place during the COVID-19 pandemic, will continue as planned. Thus, the authors conclude that the online learning conducted by SD Islam Al-Azhar 13 Rawamangun to improve students' reading and writing literacy skills has been successful. This confirms several previous research findings that support the success of online learning (online) or Learning from Home (BDR) during the covid-19 pandemic (Lapitan et al., 2021), (Sari et al., 2020), (Mok et al., ., 2021), (Pujilestari, 2020), and (Dewi, 2020).

\section{Conclusion}

Based on the results of the study, it can be concluded that research that focuses on how to develop reading and writing literacy in grade II elementary school students starts from the emergency curriculum review process, syllabus design, and learning implementation plans then continues with the implementation of learning and ends with an evaluation. Reading learning activities are focused on reading aloud reading texts, reading comprehension, and reading poetry texts. Learning to read is quite optimal. This can be seen from the number of times the students' reading tests have increased their reading skills. Learning to write is focused on writing simple poems according to pictures and writing simple texts according to pictures using punctuation marks and capital letters. In general, students can write down their ideas according to the picture, although in terms of writing there are still some students who are not correct in using capital letters and spelling. Thus, it was concluded that the online learning carried out by SD Islam Al-Azhar 13 Rawamangun to improve students' reading and writing literacy skills had been successful.

\section{References}

1. Aisyah, S., Yarmi, G., Sumantri, M. S., \& Iasha, V. (2020). Kemampuan membaca permulaan melalui pendekatan whole language di sekolah dasar. Jurnal Basicedu, 4(3), 637-643.

2. Asrifah, S., Solihatin, E., Arif, A., Rusmono, \& Iasha, V. (2020). Pengaruh Model Pembelajaran Problem Based Learning Terhadap Hasil Belajar Pendidikan Pancasila Dan Kewarganegaraan Siswa Kelas V SDN Pondok Pinang 05. Buana Pendidikan: Jurnal Fakultas Keguruan Dan Ilmu Pendidikan, 16(30 SE-), 183193. https://doi.org/10.36456/bp.vol16.no30.a2719

3. Bakry, M. S., \& Alsamadani, H. A. (2015). Improving the Persuasive Essay Writing of Students of Arabic as a Foreign Language (AFL): Effects of Self-Regulated Strategy Development. Procedia - Social and Behavioral Sciences, 182, 89-97. https://doi.org/10.1016/j.sbspro.2015.04.742

4. Dewi, W. A. F. (2020). Dampak COVID-19 terhadap Implementasi Pembelajaran Daring di Sekolah Dasar. Edukatif: Jurnal Ilmu Pendidikan, 2(1), 55-61. https://doi.org/10.31004/edukatif.v2i1.89

5. Izzaty, A. D., \& Nurfitriani, M. (2021). Pengembangan Media Pembelajaran Permainan Ludo Pada Materi Operasi Pengurangan Kelas 3 MIS Sindangraja. Buana Pendidikan: Jurnal Fakultas Keguruan Dan Ilmu Pendidikan, 17(1), 33-41. 
6. Lapitan, L. D., Tiangco, C. E., Sumalinog, D. A. G., Sabarillo, N. S., \& Diaz, J. M. (2021). An effective blended online teaching and learning strategy during the COVID-19 pandemic. Education for Chemical Engineers, 35(May 2020), 116-131. https://doi.org/10.1016/j.ece.2021.01.012

7. LISTYOWATI, A. (2018). PERKULIAHAN BERBASIS LITERASI PADA MATA KULIAH KREATIVITAS DAN KEBERBAKATAN DI ANGKATAN 2016 PG PAUD UNIVERSITAS PGRI ADI BUANA SURABAYA. Buana Pendidikan: Jurnal Fakultas Keguruan Dan Ilmu Pendidikan, 14(25 SE-), 1420. https://doi.org/10.36456/bp.vol14.no25.a1468

8. Marudut, M. R. H., Bachtiar, I. G., Kadir, K., \& Iasha, V. (2020). Peningkatan Kemampuan Berpikir Kritis dalam Pembelajaran IPA melalui Pendekatan Keterampilan Proses. Jurnal Basicedu, 4(3), 577-585.

9. McLaughlin, M. (2012). Reading comprehension: What every teacher needs to know. Reading Teacher, 65(7), 432-440. https://doi.org/10.1002/TRTR.01064

10. Mok, K. H., Xiong, W., Ke, G., \& Cheung, J. O. W. (2021). Impact of COVID-19 pandemic on international higher education and student mobility: Student perspectives from mainland China and Hong Kong. International Journal of Educational Research, 105(October 2020), 101718. https://doi.org/10.1016/j.ijer.2020.101718

11. Muhammadi, Taufina, \& Chandra. (2018). Literasi Membaca untuk Memantapkan Nilai Sosial Siswa SD. Litera, Volume 17.

12. Nurwardani, P., Nugroho, S. W., Mulyono, E., Arifin, S., Djajanto, L., Soetanto, H., \& Kusumawardani, S. S. (n.d.). Panduan Penyusunan Kurikulum Pendidikan Tinggi di Era Industri 4.0. Direktorat Jenderal Pembelajaran dan Kemahasiswaan Kementerian Riset Teknologi dan Pendidikan Tinggi.

13. Oshchepkova, T., \& Alkhaldi, A. A. (2018). How To Develop Writing Skills in a Foreign Language? European Journal of Foreign Language Teaching, 3(4), 174-185. https://doi.org/10.5281/zenodo.1647022

14. Perry, K. H. (2015). Analyzing Literacy Practice: Grounded Theory to Model Author ( $s$ ): Victoria PurcellGates, Kristen H. Perry and Adriana Briseño Source: Research in the Teaching of English, Vol . 45, No . 4 ( May 2011 ), pp . 439-458 Published by: National Council. 45(4), 439-458.

15. Prayoga, R. ., Suwignyo, H., \& Harsiati, T. (2017). Peningkatan Keterampilan Menulis Cerita Berbantuan Media Buku Cerita Anak. Jurnal Pendidikan: Teori, Penelitian, Dan Pengembangan, 2(11), 1498-1503.

16. Pujilestari, Y. (2020). Dampak Positif Pembelajaran Online Dalam Sistem Pendidikan Indonesia Pasca Pandemi Covid-19. Adalah, 4(1), 49-56. http://journal.uinjkt.ac.id/index.php/adalah/article/view/15394/7199

17. Rachamatika, T., M. Syarif Sumantri, Agung Purwanto, Jatu Wahyu Wicaksono, Alrahmat Arif, \& Vina Iasha. (2021). Pengaruh Model Pembelajaran Dan Kemandirian Belajar Terhadap Kemampuan Berpikir Kritis IPA Siswa Kelas V SDN Di Jakarta Timur. Buana Pendidikan: Jurnal Fakultas Keguruan Dan Ilmu Pendidikan, 17(1 SE-), 59-69. https://doi.org/10.36456/bp.vol17.no1.a3162

18. Rohde, L. (2015). The comprehensive emergent literacy model: Early literacy in context. SAGE Open, 5(1). https://doi.org/10.1177/2158244015577664

19. Sari, W., Rifki, A. M., \& Karmila, M. (2020). Pembelajaran Jarak Jauh Pada Masa Darurat Covid 19. 1, 12.

20. Setiadi, S. (2017). Peningkatan keterampilan kitabah arabiyah mahasiswa melalui metode tutor sebaya. AlBayan, 9(1), 1-9.

21. Spitzer, J., Ward, N., Pendidikan, T. J., Volume, P. D., Wagner, D. A., Abbas, N., Hartati, Nurharini, A., Setiawati, I. K., Rusilowati, A., Khumaedi, Vebrianto Susilo, S., Risda Garnisya, G., Majalengka, U., Membaca, K., Sekolah, S., Pamungkas, R., Probosari, R. M., Puspitasari, D., ... Listyorini, B. (2015). The Role of Knowledge in Early Literacy. Bmj, 4(1), 468-475. https://doi.org/10.1136/bmj.330.7497.948-a

22. Staker, H., \& Horn, M. B. (2012). Classifying $K-12$ Blended Learning. INNOSIGHT Institute. https://www.christenseninstitute.org/publications/classifying-k-12-blended-learning2/?_sf_s=staker\&sf_paged=8

23. Sudrajat, A., Meiliana Lovienica, \& Vina Iasha. (2021). Pengaruh Model Resource Based Learning Terhadap Hasil Belajar Ilmu Pengetahuan Sosial (IPS) Siswa Kelas IV SD Sekolah Dasar. Buana Pendidikan: Jurnal Fakultas Keguruan Dan Ilmu Pendidikan, 17(1 SE-), 70-75. https://doi.org/10.36456/bp.vol17.no1.a3217

24. Susilawati, \& Marlianingsih, N. (2018). Mengembangkan Minat Baca dan Pendidikan Karakter Melalui Gerakan Literasi Sekolah. Faktor Jurnal Ilmiah Kependidikan, 5(3), 193-198.

25. Wagner, D. (2013). Literacy and UNESCO: Conceptual and Historical Perspectives. New Directions for Adult and Continuing Education, 2013(138), 19-27. https://doi.org/10.1002/ace.20050 